\title{
Impulsive Buying Behavior in Mobile Apps Online Travel Agent (OTA) Users: The Role of Apps Browsing and Sales Promotion
}

\author{
Erris Kusumawidjaya ${ }^{1}$, Verina Wijaya ${ }^{2 *}$, Adrie Oktavio ${ }^{3}$ \\ ${ }^{1}$ Tourism Department, Universitas Ciputra Surabaya, Indonesia \\ ${ }^{*}$ Corresponding author. Email: verina.wijaya@ciputra.ac.id
}

\begin{abstract}
This study tries to explore the phenomenon of impulsive buying among Online Travel Agent (OTA) users who are influenced by the presence of sales promotion activities by OTA and consumer actions when searching for travel products offered by OTA through the mobile apps platform. Research data collection is done through the distribution of questionnaires arranged in a structured way to answer the formulation of the research problem. The questions included in the questionnaire all adopt the results of previous studies with a level of validity and reliability that can be scientifically guaranteed. Questionnaires were distributed to OTA mobile apps users who have accounts in various types of OTAs and have made purchases of products offered by OTA in the past 1 year. A total of 106 respondents participated in filling out the questionnaire from 150 questionnaires that had been distributed previously. The results show that apps browsing does not affect the impulsive behavior of OTA customers and conversely sales promotion can significantly influence impulsive buying.
\end{abstract}

Keywords: sales promotion; browsing; impulsive buying behavior; online travel agent; mobile apps

\section{INTRODUCTION}

The development of the digital world had a massive impact, including in the tourismindustry sector [1]. One of the digital tourism devices that are being used is OTA (Online Travel Agent) [2]. The existence of OTA is proven to be able to disrupt the existence of conventional travel agents. The role of the internet has made OTA more effective distribution channel than traditional travel agents [3].

There is still debate among researchers regarding the definition of Impulsive Buying Behavior (IBB) in the context of the platform used, namely purchasing online. The massive use of the internet as an information channel in the process of searching and purchasing a product as if it seems to make consumer behavior seems to have changed towards a more planned process [4]. On the other hand, some researchers claim that the internet can support
IBB [5], [6]. As such, the agreement regarding the conceptualization of IBB in the context of online purchases (in purchases through OTA) remains unclear. IBB in the tourism industry is considered different from the retail world. In the context of tourism services including OTA, IBB is considered difficult for some researchers. Decision making in tourism services is perceived as a planned process [7], [8], because travel is assumed to be high involvement activity [9]. This is confirmed by Ajzen \& Driver's research [10] when testing Theory of Planned Behavior which states that a person often uses his free time to plan his tour.

The creation of IBB in the context of online purchases is certainly influenced by many factors. The aim of the research is to develop knowledge about impulsive buying online while traveling on the mobile application platform. Specifically, this study wants to prove the extent to which IBB can be influenced by factors such as apps browsing 


\section{Procedia Business and Financial Technology}

Proceedings of the 2nd International Conference on Business and M anagement of T echnology (ICO N BM T 2020) - Part 2

and sales promotion for OTA users or members who have OTA apps on their smartphones.

\subsection{Related Work}

It must be acknowledged that the perspective of consumers when buying products sold online varies greatly, including products offered by OTA, but the impulse of hedonic as well as utilitarian behaviors such as impulsive tracking and buying is quite dominant in online product selection [11]. The hedonic behavior has prompted researchers to analyze more about online purchases, specifically the reasons why consumers prefer to buy products online, including tourism products [12]. Turkyilmaz et al. [13] also added that website personality characteristics can influence consumer search behavior that leads to shopping- related behavior. Therefore, OTA must pay special attention to IBB, both in terms of improving the quality of mobile apps and promotional programs to support the growth of their e-business.

\subsection{Our Contribution}

This study is expected to be able to contribute to OTA marketing, especially observing consumers' impulsive behavior patterns in buying a tourism product online and is motivated by the sales promotion program offered by OTA and the extent to which OTA's mobile apps platform is able to stimulate consumers to actively conduct searches. the product finally creates purchase transactions, especially those that are impulsive.

\section{THEORETICAL BACKGROUND}

\subsection{Impulsive Buying Behavior in the Context of Buying Online}

Consumers who shop online may have somewhat rational buying behavior, because consumers tend to look for information or make comparisons first before making a final decision. However, these rational decisions are not always made by consumers, thus, they open space for impulsive buying models in this online media [14], [15]. Rook [16] believes IBB is characterized by sudden consumer behavior with hedonic buying patterns that are very complex and can stimulate emotional conflict due to lack of careful consideration before buying. When buying products online, consumers usually tend to make unwanted and direct purchases right away [17], which may be related to simplicity or website involvement [18] and can also be mobile apps. In this condition, online purchases are more driven by consumer emotions, low cognitive control, or spontaneous behavior [19] so they don't take into account financial or other issues.

\subsection{Mobile Apps Browsing}

Browsing is an explorative search process that is often less focused, not directed, and driven by certain stimuli
[20]. Some previous research also shows that the purpose $90 / 180$ of someone browsing is not just to search for and collect certain information (utilitarian value), but also to have fun or to spend free time (hedonic value) [21],

[22] which is believed to be a significant predictor on a person's search behavior [23], [24].

\subsection{Sales Promotion}

Blattberg \& Neslin [25] defines sales promotion as a marketing tool that focuses on actions that have a direct impact on the company's customer behavior.

The facts have shown that consumers who use online platforms tend to look for the benefits of utilitarian value and hedonic value [24], because these two benefits most easily influence their online buying behavior [21], [22], [26]. However, for consumers who are used to using an online platform when buying a particular product or service, sales promotion is only considered an added benefit because they trust their own ability to make decisions regarding online purchases compared to consumers who are not familiar yet with the online platform [27].

\subsection{Browsing and Impulsive Buying Behavior Apps}

In the context of online purchasing, Verhagen \& Dolen [14], Bloch et al. [21] and Park \& Lennon [28] explain the findings of their research that browsing has a positive influence on consumers' desire to buy products impulsively. Browsing activities often take a relatively long time so consumers are more likely to feel the desire to buy products impulsively in the process because they are more susceptible to environmental influences [20], [29]. Based on the explanation above, the first hypothesis of this research is formulated as follows:

H1. There is a positive relationship between browsing apps and impulsive buying behavior

\subsection{Sales Promotion and Impulsive Buying Behavior}

In the context of purchasing online-based tourism products such as those offered by OTA, sales promotion can certainly play the same role in providing stimulus for the creation of IBB. Although IBB in the context of purchasing tourism products is a planned IBB according to Laesser \& Dolnicar [30], nonetheless sales promotion can potentially reduce consumer planning in buying tourism products, for example due to the availability of last minute offers (such as flight ticket costs and hotel vouchers), so consumers end up behaving impulsively. Based on the explanation above, the first hypothesis of this research is formulated as follows:

H2. There is a positive relationship between sales promotion and impulsive buying behavior 


\section{Procedia Business and Financial Technology}

Proceedings of the 2 nd International Conference on Business and M anagement of T echnology (ICO N BM T 2020) - Part 2

\section{RESEARCH METHOD}

In this study, the population was the users of various types of OTA apps based on mobile. Purposive sampling was chosen as a sampling technique based on several sample criteria; i.e. that is over 17 years old, has an active account on OTA mobile apps and has used the mobile apps for transactions in the past one year.

Data collection was carried out in a cross- sectional survey from mid-February 2020 to early March 2020. The questionnaire was created in the Google form format and distributed online to 150 OTA mobile apps users both via email and WhatsApp chat. From the 150 questionnaires distributed, 114 questionnaires (76\%) were sent back to the researcher Next the researcher examined the completeness of the data contents of 114 questionnaires and it turned out that there were 8 questionnaires that were incomplete filling in the data. Therefore, the total sample used in this study was 106 samples. Furthermore, the 106 questionnaires were processed using multiple linear regression analysis with IBM SPSS version 22.0.

The browsing apps variable is measured using Park \& Kim's [11] two indicators. Sales promotion variable as the second independent variable in this study was measured by five indicators adapted from Kotler \& Keller [31]. Dependent variables namely IBB are measured using four indicators from Rook's research [16].

\section{RESULT ANDDISCUSSION}

The majority of respondents in this study were women as many as 88 respondents $(83 \%)$, while the remaining 18 respondents $(17 \%)$ were men. From the age factor, 48 respondents (45.3\%) were aged between 17-22 years; 42 respondents (39.5\%) were aged between 23-28 years; and the rest are divided into several categories of ages 29-34 years $(5.7 \%), 35-40$

years (3.8\%), 41-45 years (1.9\%), and aged over 45 years $(3.8 \%)$. From the occupation, a total of

56 were students (52.8), 23 were employee (21.8\%), 16 respondents were businessperson (15.2\%), six respondents were professional (5.7\%); and five respondents $(4.5 \%)$ have other occupation, such as housewives. The majority of the respondents were using Traveloka, followed by Tiket.com, Pegipegi, and 10.4\% were using other OTA account. Most respondents were buying flight ticket from OTA, followed by hotel voucher, train ticket, tour package, and $0,9 \%$ were buying other products.

\subsection{Validity \& Reliability}

Validity testing uses the Pearson Correlation test (see Table 1) and Cronbach's Alpha for reliability testing (see Table 2).
Table 1. Validity Test Results

\begin{tabular}{|c|c|c|c|c|}
\hline Variable & ItemF & $\begin{array}{l}\text { Pearson } \\
\text { Correlation }\end{array}$ & $\begin{array}{l}\text { Sig. (2- } \\
\text { tailed }\end{array}$ & $\mathbf{N}$ \\
\hline \multirow{2}{*}{\begin{tabular}{|l|} 
Apps \\
Browsing
\end{tabular}} & $\mathrm{X} 1.1$ & $.723 * *$ & .000 & 106 \\
\hline & $\mathrm{X} 1.2$ & $.761 * *$ & .000 & 106 \\
\hline \multirow{5}{*}{$\begin{array}{l}\text { Sales } \\
\text { Promotion }\end{array}$} & $\mathrm{X} 2.1$ & $.621 * *$ & .000 & 106 \\
\hline & $\mathrm{X} 2.2$ & $.731 * *$ & .000 & 106 \\
\hline & $\mathrm{X} 2.3$ & $.773^{* * *}$ & .000 & 106 \\
\hline & $\mathrm{X} 2.4$ & $.696^{* *}$ & .000 & 106 \\
\hline & $\mathrm{X} 2.5$ & $703 * *$ & .000 & 106 \\
\hline \multirow{4}{*}{ IBB } & Y1.1 & $.773 * *$ & .000 & 106 \\
\hline & Y1.2 & $.729 * *$ & .000 & 106 \\
\hline & Y1.3 & $.761 * *$ & .000 & 106 \\
\hline & Y1.4 & $807 * *$ & .000 & 106 \\
\hline
\end{tabular}

It can be seen in Table 1 above that all indicators used to measure all variables are valid. Therefore, each item from the questionnaire was considered suitable to measure the three variables of this study.

Table 2. Reliability Test Results

\begin{tabular}{|l|l|l|}
\hline \multicolumn{1}{|c|}{ Variable } & $\begin{array}{l}\text { Cronbach's } \\
\text { Alpha }\end{array}$ & N of Items \\
\hline Apps Browsing & .743 & 2 \\
\hline Sales Promotion & 746 & 5 \\
\hline Impulsive Buying Behavior & .794 & 4 \\
\hline
\end{tabular}

Table 2 shows the Cronbach's Alpha value of the three variables has a value above 0.6 . Thus, it can be said that the instruments used arereliable.

\subsection{Hypothesis Test \& Determination Coefficient}

The results of hypothesis testing are summarized in Table 3. The results of the first hypothesis test produce a regression coefficient of 0.124 with a significance value of 0.441. Because the significance value $>0.05$, it can be concluded that IBB is not influenced by apps browsing so the first hypothesis is rejected. Furthermore, the results of the second hypothesis produce a regression coefficient of 0.504 with a significance value of 0.000 . Because the significance value $<0.05$, there is a positive and significant effect between sales promotion and IBB. That is, the second hypothesis is accepted.

In Table 3 it is known that the $\mathrm{R}^{2}$ value is 0.296 which means that the ability of the independent variables in this study are apps Browsing and sales promotion in explaining the variance of the dependent variable or IBB is $29.6 \%$. Means there are $70.4 \%$ variance of the dependent variable explained by other factors outside this study.

Furthermore, the adjusted $\mathrm{R}^{2}$ value of 0.280 is the ability of the independent variables in this study, namely apps browsing and salespromotion in explaining the variance 


\section{Procedia Business and Financial Technology}

Proceedings of the 2nd International Conference on Business and M anagement of T echnology (ICO N BM T 2020) - Part 2

of the dependent variable or IBB is $28 \%$, the remaining $72 \%$ is explained by other factors outside this study.

For the record, research using survey data (primary data) that is cross section in nature then $\mathrm{R}^{2}$ with a value of 0.2 or 0.3 can be said to be good enough.

Table 3 Summary of Regression Analysis Results

\begin{tabular}{|c|c|c|c|c|c|}
\hline \multirow[t]{2}{*}{ Dependent Variable } & \multirow{2}{*}{ Model } & \multicolumn{2}{|c|}{ Unstandardized Coefficients } & \multirow{2}{*}{ t statistic } & \multirow{2}{*}{ Sig. } \\
\hline & & $\bar{B}$ & Std. Error & & \\
\hline \multirow{5}{*}{$\begin{array}{l}\text { Impulsive Buying } \\
\text { Behavior (Y) }\end{array}$} & (Constant) & -0.597 & & -0.268 & 0.790 \\
\hline & Apps Browsing (X1) & 0.124 & 0.161 & 0.773 & 0.441 \\
\hline & Sales Promotion (X2) & 0.504 & 0.120 & 4.208 & 0.000 \\
\hline & $R$-squared $\left(\mathrm{R}^{2}\right)$ & $=0.296$ & & & \\
\hline & Adjusted $\mathrm{R}^{2}$ & $=0.280$ & & & \\
\hline
\end{tabular}

\subsection{Discussion}

Based on the results, it is stated that the first hypothesis was rejected. This means that browsing activity in the context of purchasing tourist products through the OTA mobile apps platform has no influence on IBB. This finding contrasts with most previous research results such as Verhagen \& Dolen [14], Zhang et al. [32] and Wahab et al. [33] However research by Zheng et al [34] is in line with the findings of this study. Although Zheng et al. [34] conducted his research in the online retail market but his opinion in explaining the reasons why apps browsing has no effect on IBB is worth observing.

Zheng et al. [34] argues that impulsive purchases of consumers cannot simply happen when consumers are browsing on their smartphones but need to be studied related to the consumer's motivation in shopping. What motivated consumers with a high potential for making impulsive purchases when they are browsing on their smartphones? This key question refers to an explanation of hedonic and utilitarian motivations that have been explained in the previous section.

As explained earlier that consumers who have hedonic motivation in shopping usually spend more time in product exploration, and they enjoy the exploration process as pleasure in fulfilling their desires which can further increase impulsive purchases [35]-[37]. Compared to consumers with utilitarian motives, consumer product search with hedonic motives has a stronger influence on consumers' desire to buy impulsively [34], [38]. Hedonic motivation plays an important role in individual behavioral intentions and should not be ruled out without giving any reason[39].

Based on these explanations and related to the findings of this study, it can be presumed that most of the samples of this study have utilitarian motivation in tracing products so that they do not affect impulsive buying. Utilitarian consumers are very concerned in meeting consumption needs that are in line with their expectations, so they tend to have no direct intention in IBB [34]. Researchers deliberately use the word "allegedly" because this research does not detect explicitly and clearly about the background of hedonic and utilitarian motivations of existing samples so that this can also provide space for further research.

Another explanation that might be considered as a reason to answer why the first hypothesis of this study was rejected is referring to the opinion of Laesser \& Dolnicar [30] related to the characteristics of the products offered by OTA itself. Laesser \& Dolnicar [30] explained that IBB in the context of tourism products would be more difficult to occur and more planned in nature when compared to retail products. This is because consumers will at least consider taking vacation time before ordering or buying tourism products offered by OTA. The time spanbetween making the decision to take a vacation and the scheduled departure is a maximum of seven days or one week. It is assumed that consumers involved in impulsive buying usually had certain categories of tourism products in their minds to buy immediately but had not yet decided which brands to buy.

Associated with the results of testing the second hypothesis, the findings of this study are in accordance with the framework of developing hypotheses in the previous section while supporting the results of previous studies such as Ali et al. [40] and Xu \& Huang [41]. Sales promotion is proven to be able to play a positive role in influencing IBB users of OTA mobile apps in Indonesia. This means that OTA has done the right way in promoting tourism products online through the mobile apps platform and other online platforms [42], so that it can trigger consumers to behave impulsively in the process of purchasing these products. In addition, if it is associated with the concept of planned impulsive purchases as proposed by Laesser \& Dolnicar [30], the sales promotion conducted by OTA is seen as being able to reduce consumer planning in buying tourism products, for example due to the availability of last minute offers (such as flight ticket costs and vouchers hotel), so consumers 


\section{Procedia Business and Financial Technology}

Proceedings of the 2nd International Conference on Business and M anagement of T echnology (ICO N BM T 2020) - Part 2

end up behaving impulsively. Like the offline purchase model, OTA users are also easily tempted and trapped in an impulsive buying model when faced with various sales promotion offers such as discounts, cashback, and other forms of promotion. OTA users feel benefited from the sales promotion that in turn makes them buy tourism products that might not have been planned or thought of before [40], [41]. OTA users in Indonesia still place sales promotion as one of the main benchmarks in making purchasing decisions including impulsive purchases. This is in line with the opinion of Winarko \& Husna [43] which revealed that OTA customers will continue to buy hotel vouchers and / or flight tickets from the OTA website and do not care about the quality of the OTA services. So, there is a possibility that an OTA with a quality service that is not too good but is able to provide sales promotion that is more attractive but attractive to consumers For OTA users in Indonesia, sales promotion is also used as a justification in the decision- making process, including impulsive purchases. IBB is seen as a risk-taking step when consumers get compensation or incentives from sales promotion.

\section{CONCLUSION}

The two hypotheses in this study were not entirely accepted. The first hypothesis was not proven so that browsing apps had no effect on IBB OTA users in Indonesia. While the second hypothesis, namely OTA sales promotion, was able to significantly influence IBB. This research also provides a loophole for further research, namely the need to specifically identify consumers' motivation to shop online, especially in the context of OTA product search activities on mobile apps. Motivation is important to be studied because both hedonic or utilitarian motivation each has unique and different characteristics so that the approach will certainly also be different.

\section{REFERENCES}

[1] G. Kaur, "The importance of digital marketing in the tourism industry," Int.J. Res., vol. 5, no. 6, p. 72, 2017.

[2] S. Talwar, A. Dhir, P. Kaur, and M. Mäntymäki, "Why do people purchase from online travel agencies (OTAs)? A consumption values perspective," Int. J. Hosp. Manag., vol. 88, 2020.

[3] H. A. Lee, B. Denizci Guillet, and R. Law,“An examination of the relationship between online travel agents and hotels: A case study of choice hotels international and Expedia.com," Cornell Hosp. Q., vol. 54, no. 1, pp. 95-107, 2013.

[4] C. Katawetawaraks and C. L. Wang, "Online shopper behavior: Influences of online shopping decision," Asian J. Bus. Res., vol. 1, no. 2, 2011.

$93 / 180$

[5] L. Aragoncillo and C. Orús, "Impulse buying behaviour: An online-offline comparative and the impact of social media," Spanish J. Mark. - ESIC, vol. 22, no. 1, pp. 42-62, 2018.

[6] S. H. Lim, S. Lee, and D. J. Kim, "Is online consumers' impulsive buying beneficial for ecommerce companies? An empirical investigation of online consumers' past impulsive buying behaviors," Inf. Syst. Manag., vol. 34, no. 1, pp. 85-100, 2017.

[7] P. Baruca and Ž. Civre, "How do guests choose a hotel?," Acad. Tur. - Tour. Innov. J., vol. 5, no. 1, pp. 75-84, 2012.

[8] M. Shobeirinejad, T. Veitch, J. C. R. Smart,N. Sipe, and M. Burke, "Destination choice decisions of retail travellers: Results from discrete choice modelling in Brisbane," in Australasian Transport Research Forum, ATRF 2013 - Proceedings, 2013.

[9] C. J. Clements and B. Josiam, "Role of involvement in the travel decision," J. Vacat. Mark., vol. 1, no. 4, pp. 337-348, 1995.

[10] I. Ajzen and B. L. Driver, "Application of the Theory of Planned Behavior toleisure choice," $J$. Leis. Res., vol. 24, no. 3, pp. 207-224, 1992.

[11] E.-J. Park and E.-Y. Kim, "Effects of consumer tendencies and positive emotion on impulse buying behavior for apparel," J. Korean Soc. Cloth. Text., vol. 32, no. 6, pp. 980-990, 2008.

[12] A. M. Susskind and M. A. Stefanone, "Internet apprehensiveness: An examination of on-line information seeking and purchasing behavior," J.Hosp. Tour. Technol., vol. 1, no. 1, pp. 5-29, 2010.

[13] C. A. Turkyilmaz, S. Erdem, and A. Uslu, "The effects of personality traits and website quality on online impulse buying," Procedia - Soc. Behav. Sci., vol. 175, pp. 98-105, 2015.

[14] T. Verhagen and W. Van Dolen, "The influence of online store beliefs on consumer online impulse buying: A model and empirical application," Inf. Manag., vol. 48, no. 8, pp. 320-327, 2011.

[15] S. A. Jeffrey and R. Hodge, "Factors influencing impulse buying during an online purchase," Electron. Commer. Res., vol. 7, no. 3-4, pp. 367379, 2007.

[16] D. W. Rook, "The buying impulse," J. Consum. Res., vol. 14, no. 2, p. 189, 1987.

[17] M. A. Jones, K. E. Reynolds, S. Weun, and S. E. Beatty, "The product-specific nature of impulse buying tendency," J. Bus. Res., vol. 56, no. 7, pp. 505-511, 2003.

[18] K. Wu, J. Vassileva, Y. Zhao, Z. Noorian, W. Waldner, and I. Adaji, "Complexity or simplicity? Designing product pictures for advertising in online marketplaces," J. Retail. Consum. Serv., 


\section{Procedia Business and Financial Technology}

Proceedings of the 2nd International Conference on Business and M anagement of T echnology (ICO N BM T 2020) - Part 2

vol. 28, pp. 17-27, 2016.

[19] P. Sharma, B. Sivakumaran, and R. Marshall, "Impulse buying and variety seeking: A traitcorrelates perspective,"J. Bus. Res., vol. 63, no. 3, pp. 276-283, 2010.

[20] W. W. Moe, "Buying, searching, or browsing: Differentiating between online shoppers using instore navigational clickstream," J. Consum. Psychol., vol. 13, no. 1-2, pp. 29-39, 2003.

[21] P. H. Bloch, D. L. Sherrell, and N. M. Ridgway, "Consumer search: Anextended framework," J. Consum. Res., vol. 13, no. 1, p. 119, 1986.

[22] A. Floh and M. Madlberger, "The role of atmospheric cues in online impulse-buying behavior," Electron. Commer. Res. Appl., vol. 12, no. 6, pp. 425-439, 2013.

[23] E. Pöyry, P. Parvinen, and T. Malmivaara, "Can we get from liking to buying? Behavioral differences in hedonic and utilitarian Facebook usage," Electron. Commer. Res. Appl., vol. 12, no. 4, pp. 224-235, 2013.

[24] P. L. To, C. Liao, and T. H. Lin, "Shopping motivations on Internet: A study based on utilitarian and hedonic value," Technovation, vol. 27, no. 12, pp. 774-787, 2007.

[25] R. Blattberg and S. Neslin, Sales promotion: Concepts, methods and strategies, 2nd ed. New Jersey: Prentice Hall, 1990.

[26] C. Y. Yoo, "Implicit memory measures for web advertising effectiveness," Journal. Mass Commun. Q., vol. 84, no. 1, pp. 7-23,2007.

[27] E. Crespo-Almendros and S. Del Barrio-García, "Online airline ticket purchasing: Influence of online sales promotion type and Internet experience," J. Air Transp. Manag., vol. 53, pp. 23-34, 2016.

[28] J. Park and S. J. Lennon, "Psychological and environmental antecedents of impulse buying tendency in the multichannel shopping context," $J$. Consum. Mark., vol. 23, no. 2, pp. 58-68, 2006.

[29] C. Janiszewski, "The influence of display characteristics on visual exploratory search behavior," J. Consum. Res., vol. 25, no. 3, pp. 290 301, 1998.

[30] C. Laesser and S. Dolnicar, "Impulse purchasing in tourism - learnings from a study in a matured market," Anatolia, vol. 23, no. 2, pp. 268-286, 2012.

[31] P. Kotler and K. L. Keller, Marketing Management, 15th ed. Harlow: Pearson Education, 2016.

[32] K. Z. K. Zhang, H. Xu, S. Zhao, and Y.Yu, "Online reviews and impulse buying behavior: The role of browsing and impulsiveness," Internet Res., vol. 28, no. 3, pp. 522-543, 2018.
[33] Z. Wahab, M. S. Shihab, A. Hanafi, and H.F. Mavilinda, "The influence of online shopping motivation and product browsing toward impulsive buying of fashion products on a social commerce," J. Manaj. Motiv., vol. 14, no. 1, p. 32, 2018.

[34] X. Zheng, J. Men, F. Yang, and X. Gong, "Understanding impulse buying inmobile commerce: An investigation into hedonic and utilitarian browsing," Int. J. Inf. Manage., vol. 48, pp. 151-160, 2019.

[35] S. E. Beatty and M. E. Ferrell, "Impulse buying: Modeling its precursors," J. Retail., vol. 74, no. 2, pp. 169-191, 1998.

[36] G. N. Punj and R. Staelin, “A model of consumer information search behavior for new automobiles," J. Consum. Res., vol. 9, no. 4, p. 366, 1983.

[37] F. Erkip, "The rise of the shopping mall in Turkey: The use and appeal of a mall in Ankara," Cities, vol. 22, no. 2, pp. 89-108, 2005.

[38] E. J. Park, E. Y. Kim, V. M. Funches, and W. Foxx, "Apparel product attributes, web browsing, and eimpulse buying on shopping websites," J. Bus. Res., vol. 65, no. 11, pp. 1583-1589, 2012.

[39] K. Tamilmani, N. P. Rana, N. Prakasam, and Y. K. Dwivedi, "The battle of Brain vs. Heart: A literature review and meta-analysis of 'hedonic motivation' use in UTAUT2," International Journal of Information Management, vol. 46. pp.222-235, 2019.

[40] S. F. S. Ali, Y. Abdul Aziz, R. N. Raja Yusuf, and S. I. Ng, "Evaluation the role of sales promotion in influencing impulse buying behavior: A comparison between international and local tourist at premium outlet in Malaysia," J. Tour. Hosp. Environ. Manag., pp. 32-43, 2019.

[41] Y. Xu and J. S. Huang, "Effects of price discounts and bonus packs on online impulse buying," Soc. Behav. Pers., vol. 42, no. 8, pp. 1293-1302, 2014.

[42] M. I. Rosyidi, "Indonesian online travel agencies: Profiling the services, employment, and users," in The 3rd International Seminar on Tourism (ISOT 2018), 2019.

[43] H. B. Winarko and A. Husna, "The consumer behavior toward Online Travelling Agency (OTA): Evidence from Indonesia," Int. J. Tour. Hosp. Rev., vol. 7, no. 1, pp. 20-29, 2020. 